\title{
PENERAPAN STRATEGI JOYFULL LEARNING DALAM PENANAMAN SIKAP TANGGUNG JAWAB SISWA (STUDI KASUS PEMBELAJARAN IPS DI SMP NEGERI 1 MLARAK)
}

\author{
Arsyad Muhammad Sajjad', Muhammad Widda Djuhan² \\ ${ }^{1}$ Institut Agama Islam Negeri Ponorogo, \\ arsyad11muhammad@gmail.com \\ ${ }^{2}$ Institut Agama Islam Negeri Ponorogo \\ djuhan@iainponorogo.ac.id
}

\begin{abstract}
ABSTRAK
Penelitian ini dilatarbelakangi oleh rendahnya tanggung jawab siswa terdahap tugas yang telah diberikan oleh guru di SMP Negeri 1 Mlarak. Oleh karena itu perlu adanya penerapan strategi pembelajaran yang sederhana dilakukan oleh guru dan menyenangkan bagi para siswa sehingga dapat menanamkan sikap tanggung jawab siswa. Tujuan penelitian ini untuk mengetahui peningkatan dari sikap tanggung jawab siswa melalui lima langkah dalam strategi Joyfull Learning. Penelitian kualitatif ini dilaksanakan tiga teknik dalam pengumpulan data dengan teknik wawancara, observasi dan dokumentasi. Subyek penelitian ini adalah guru IPS dan siswa di SMP Negeri 1 Mlarak. Instrumen yang digunakan adalah lembar wawancara, observasi dan dokumentasi sikap tanggung jawab siswa. Hasil penelitian menunjukkan strategi Joyfull Learning dalam penanaman sikap tanggung jawab siswa terhadap tugas mengalami peningkatan yaitu pertama, menyelesaikan tugas dengan baik dan tepat waktu. Kedua, antusias dan bersemangat menerima tugas yang diberikan oleh guru.
\end{abstract}

Kata kunci: Joyfull Learning, Tanggung Jawab.

\section{ABSTRACT}

This research was motivated by the low responsibility of students due to the assignments given by the teacher at SMP Negeri 1 Mlarak. Therefore it is necessary to implement learning strategies that are simple and fun for students so that they can instill an attitude of student responsibility. The purpose of this study was to determine the increase in student responsibility attitudes through five steps in the Joyful Learning strategy. This qualitative research carried out three techniques in data collection with interview, observation and documentation techniques. The subjects of this study were social studies teachers and students at SMP Negeri 1 Mlarak. The instruments used were interview sheets, observation and documentation of student responsibility attitudes. The results showed that the joyful learning strategy in cultivating students' responsibility towards assignments had increased, namely first, completing assignments well and on time. Second, enthusiastic and eager to accept the assignment given by the teacher.

Keywords: Joyful Learning, Responsibility

\section{PENDAHULUAN}

Pendidikan memiliki peran yang sangat penting dalam mencerdaskan kehidupan bangsa, oleh karena itu pendidikan menuntut orang-orang yang terlibat 


\section{Penerapan Strategi Joyfull Learning Dalam Penanaman Sikap Tanggung Jawab Siswa (Studi Kasus Pembelajaran IPS Di SMP Negeri 1 Mlarak)}

di dalamnya untuk bekerja sama secara maksimal, bertanggung jawab dan kesetiaan yang tinggi dalam meningkatkan mutu pendidikan yang lebih baik. Melalui pendidikan inilah suatu bangsa dapat menjadi bangsa yang kuat, berdikari dan berkarakter dan mampu bersaing dengan bangsa lain. Selain itu, pendidikan juga dipandang sebagai salah satu kategori yang memiliki peran utama dalam mempersiapkan sekaligus mencetak generasi muda di masa yang akan datang.

Sikap bosan, malas, menunda-nunda pekerjaan, mencari-cari alasan adalah beberapa sikap yang mencerminkan sikap kurang bertanggung jawab. Menanamkan sikap tanggung jawab dapat terwujud melalui berbagai cara supaya siswa tertanam sikap tanggung jawab. Mulai dari menjadi seorang guru yang penyayang, menciptakan sebuah lingkungan yang menyenangkan, ruang kelas yang nyaman, mengajarkan nilai-nilai yang baik, melibatkan siswa dalam pengambilan keputusan dan masih banyak lagi. Pada dasarnya tertanamnya sikap tanggung jawab akan mendapat hasil yang maksimal jika cara-cara tersebut diterapkan secara berulang-ulang.

Tanggung jawab pada Kamus Besar Bahasa Indonesia adalah suatu kondisi yang di mana wajib menanggung segala sesuatu, sehingga berkewajiban menanggung resiko apapun yang diterima. ${ }^{1}$ Tanggung jawab adalah sikap dan perilaku seseorang untuk menjalankan tugas dan kewajibannya terhadap diri sendiri, masyarakat, lingkungan, negara dan Tuhan Yang Maha Esa. ${ }^{2}$ Dari pengertian tersebut, tanggung jawab adalah pola tingkah laku yang secara sadar berkewajiban menjalankan segala sesuatu yang ia terima.

Peniliti menyadari bahwasannya proses penaman tanggung jawab begitu penting dalam kegiatan pembelajaran. Sebagai bentuk penerapan strategi seorang guru dalam penanaman sikap tanggung jawab siswa tidak hanya melihat dari segi peserta didik seksama dalam mendengarkan, mencatat materi yang telah disampaikan guru, akan tetapi yang terjadi sesungguhnya siswa bertanggung jawab secara penuh dari setiap kegiatan didalam sebuah kegiatan belajar mengajar.

\footnotetext{
1 Kamus Umum Besar Bahasa Indonesia, Departemen Pendidikan dan Kebudayaan, (Jakarta: Balai Pustaka, 1998) hal. 1006.

2 Jurnal konseling gusjigang Vol. 2 No. 1 (Januari-Juni 2016) Print ISSN 2460-1187, Online ISSN 2503-281X. Peningkatan Karakter Tanggung Jawab Siswa SD Melalui Penilaian Produk Pada Pembelajaran Mind Mapping. Ratri Rahayu.
} 
Peniliti mendapat berbagai pengalaman ketika mengarungi proses belajar mengajar, terutama pengalaman yang tidak menyenangkan ketika berproses dalam belajar mengajar. Salah satu pengalaman yang telah peniliti alami sewaktu melakukan observasi pada salah satu sekolah dalam pembelajaran IPS yaitu banyaknya siswa meninggalkan pelajaran sebelum pelajaran selesai, tidur waktu pembelajaran berlangsung., tidak jarang juga ada beberapa yang memilih keluar kelas untuk membeli jajan di kantin sekolah. Ketika jam pelajaran IPS telah selesai, peniliti mencoba mewawancarai beberapa siswa, kemudian mereka beralasan guru mata pelajaran IPS galak dan seringnya menyuruh siswa mengerjakan tugas. Dari fakta yang peniliti dapati mengindikasikan bahwa mata pelajaran IPS termasuk salah satu mata pelajaran yang kurang disukai siswa. Oleh karena itu apa yang dicerminkan para siswa menjadi sebuah alasan yang mendasar untuk tidak bertanggung jawab terhadap tugas yang diberikan oleh guru.

Pengalaman tidak menyenangkan dalam suasana belajar tidak hanya peniliti alami semasa observasi di satu sekolah, tetapi juga peniliti alami di lain sekolah yang berkedudukan sangat favorit di Ponorogo. Peneliti dapati dari kejadian yang dilakukan siswa yaitu ramai, keluar kelas sebelum pelajaran selesai. Seringnya siswa keluar kelas sering peniliti dapati tengah nongkrong di area kamar mandi sekolah, tidak jarang juga ada beberapa siswa yang lebih memilih dikeluarkan dari kelas. Kejadian tersebut peniliti dapati terjadi pada mata pelajaran IPS. Sewaktu peniliti dapati ada salah satu siswa yang sedang duduk di luar kelas saat pembelajaran berlangsung. Peniliti dekati kemudian mengajukan beberpa pertanyaan kepada siswa tersebut perihal kenapa dia duduk-duduk di luar kelas saat pembelajaran berlangsung, dengan wajah gembira yang ditampilkan dan jawaban yang sedikit menggelitik bagi peniliti yaitu dia sangat senang di keluarkan kelas karena beranggapan guru tersebut membosankan dan tidak menyenangkan. Dari hasil penelitian di atas, menunjukkan dampak buruk yang berimbas terhadap sikap tanggung jawa siswa terhadap kegiatan belajar mengajar terkhusus pada tugas yang diberikan oleh guru.

Dari hasil pengamatan peniliti dan disertai pendukung pendapat Darmansyah bahwasannya suasana membosankan atau tidak meyenangkan yang mereka terima, justru akan memicu bereaksinya otak reptil. Bereaksinya otak reptil itu akan memunculkan berbagai tindakan dan perilaku peserta didik yang 


\section{Penerapan Strategi Joyfull Learning Dalam Penanaman Sikap Tanggung Jawab Siswa (Studi Kasus Pembelajaran IPS Di SMP Negeri 1 Mlarak)}

bukan saja tidak mendukung terciptanya proses pembelajaran bermutu, melainkan dapat merusak pembelajaran. Reaksi yang terlihat dari setiap individu biasanya muncul stress, bosan, mengantuk, hilang motivasi, sering izin keluar kelas, ngobrol sama teman, dan lain-lain. ${ }^{3}$

Hal ini membuktikan bahwa kejadian yang peniliti alami diatas mengindikasikan ketidaknyamanan dalam proses pembelajaran. Tampak jelas dengan ditunjukkan siswa ramai dan seringya keluar kelas. Kenyataan yang terjadi di lapangan tidak sesuai dengan harapan. Seringnya siswa mendapat lingkungan belajar yang tidak menyenangkan justru berpengaruh dalam hasil belajar siswa. Banyak pakar berpendapat bahwasannya tidak terciptanya proses pembelajaran yang tidak menyenagkan disebabkan banyak faktor yang mempengaruhi. Namun faktor yang paling berpengaruh atas proses pembelajaraan yang terjadi di sekolah adalah guru.

Menurut Darmansyah siswa sering dihadapkan pada situasi yang tidak bersahabat diakibatkan karena ketidakmampuan guru memberikan stimulus yang tidak menyenangkan. Tindakan guru sering membuat mereka stress, jenuh, bosan dan tidak nyaman dalam pembelajaran. ${ }^{4}$ Hal ini tidak bisa dipungkiri bahwasannya guru sebagai stakeholder yang menjalankan roda berjalannya proses pembelajaran. Maka dari itu sebagai seorang guru harus mampu menyuguhkan strategi pembelajaran yang menyenangkan untuk para siswa.

Menurut Dryden dan Vos yang dikutip oleh Darmansyah mengungkapkan bahwa bila guru mampu merancang strategi yang tepat, maka ruang kelas dapat menjadi "rumah" tempat siswa tidak hanya terbuka terhadap umpan balik, tetapi juga mencari tempat mereka belajar, mengakui dan mendukung orang lain, tempat mereka mengalami kegembiraan dan kepuasaan, memberi dan menerima, belajar dan tumbuh. ${ }^{5}$ Dari uraian di atas, strategi pembelajaran harus mampu menciptakan lingkungan belajar yang menyenangkan, seperti kutipan di atas mampu menjadi "rumah" yang memberikan suasana yang nyaman tempat mengalami kegembiraan. Bahwa mengubah sikap negatif siswa bisa dengan menerapkan

\footnotetext{
3 Darmansyah, Strategi Pembelajaran Menyenangkan dengan Humor, (Jakarta: PT. Bumi Aksara, 2011), 11.

${ }^{4}$ Ibid.

${ }^{5}$ Ibid.
} 
pembelajaran yang menyenangkan supaya membuat siswa lebih mudah dan siap belajar.

Disisi lain dalam praktiknya strategi pembelajaran yang menyenangkan harus mempu menanamkan dan mengembangkan nilai karakter siswa. Seperti yang didefinisikan menurut Zubaedi yang dikutip oleh Syamsul Kurniawan bahwa pendidikan karakter adalah pendidikan budi pekerti plus, yang intinya merupakan progam pengajaran yang bertujuan mengembangkan watak dan tabiat peserta didik dengan cara menghayati nilai-nilai dan keyakinan masyarakat sebagai kekuatan moral dalam hidupnya melalui kejujuran, dapat dipercaya, disiplin, dan kerja sama yang menekankan ranah afektif (perasaan/sikap). ${ }^{6}$ Hal ini jelas bahwasannya strategi pembelajaran yang diterapkan guru harus mampu menajadi jalan untuk dapat menanamkan pendidikan karakter siswa.

Karakter yang harus dimiliki siswa meliputi 18 nilai pendidikan karakter salah satunya adalah sikap tanggung jawab. Melihat dari permasalahan yang peniliti alami dalam paragraf awal, jika siswa dalam proses pembelajaran mendapat pelayanan yang tidak menyenangkan dan membosankan, maka akan berdampak pada tanggung jawab terhadap tugas yang telah diberikan guru dan kewajiban disiplin di kelas akan diabaikan. Dari berbagai proses dan hasil yang peniliti alami, Strategi pembelajaran yang diusung guru seyogyanya mampu mengoptimalkan hasil belajar siswa dan membentuk karakter siswa.

Sebelum peniliti menutup latar belakang yang penulis tulis, satu poin penting yang harus peniliti sampaikan. Peneliti mencoba memahami bahwasannya dalam menerapkan pembelajaran yang memprioritaskan kebahagiaan mungkin tampak seperti sesuatu yang abstrak untuk diterapkan. Hal tersebut mungkin akan peiliti lebih sederhanakan dalam memahami: terkadang beberapa penulis membutuhkan tempat yang lebih terisolir dari keramaian untuk membuat dirinya lebih nyaman untuk mendapat insipirasi baru.

Ketika kita mencari insiparsi untuk sebuah tulisan yang lebih baik, kita memprioritaskannya sebelum memulai menulis, seperti menyeduh secangkir kopi atau mencari tempat yang terisolir dari keramaian. Hal tersebut yang menjadi daya tarik peneliti untuk menjadikan strategi joyfull learning sebagai alternatif solusi

${ }^{6}$ Syamsul Kurniawan, Pendidikan Karakter: Konsepsi dan Implementasi secara Terpadu di Lingkungan Keluarga, Sekolah, Perguruan TInggi, dan Masyarakat, (Yogyakarta: Ar-Ruzz Media, 2013), 30. 
menanamkan sikap tanggung jawab siswa dengan dibuktikan diantara lain, pertama, menyelesaikan tugas dengan baik dan tepat waktu. Kedua, antusias dan bersemangat menerima tugas yang diberikan oleh guru. Adapun keunggulan dari strategi joyfull learning sebagai berikut :

1. Strategi pembelajaran ini lebih sederhana diterapkan oleh guru, karena tidak membutuhkan alat penunjang pembelajaran yang banyak.

2. Strategi pembelajaran ini banyak menggunakan lingkungan sekitar sebagai penunjang pembelajaran, sehingga lebih memberikan pengalaman belajar yang nyata.

3. Strategi pembelajaran ini terbukti memberikan kemudahan bagi guru dan menyenangkan bagi para siswa.

\section{METODE PENELITIAN}

Metodologi yang digunakan dalam penelitian ini menggunakan pendekatan kualitatif, mempunyai definisi cara ilmiah guna memperpleh data yang valid (soheh) memiliki tujuan dapat ditemukan, dibuktikan serta dikembangkan suatu pengetahuan sehingga bisa dipakai untuk memahami, memecahkan dan mengantisipasi permasalahan didalam data serta memiliki tingkat akurasi yang mendalam. ${ }^{7}$

Denzin dan Lincoln menyatakan bahwa penelitian kualitatif adalah penelitian yang menggunakan latar belakang alamiah, dengan maksud menafsirkan fenomena yang terjadi dan dilakukan dengan jalan melibatkan metode yang ada dalam penelitian kualitatif. Metode yang biasanya dimanfaatkan adalah wawancara, pengamatan, dan pemanfaatan dokumen. ${ }^{8}$. Teknik pengumpulan data yang dimaksud adalah observasi, wawancara, dan dokumentasi. Bagi peneliti kualitatif menemukan fenomena melaui observasi, malalui wawancara yang mendalam untuk mendapat data yang dibutuhkan untuk penelitian, dan didukung lewat dokumentasi.

Tahapan ini diawali dari mendapat kasus yang memiliki keunikan, yang mana prosesnya secara induktif, teori yang dipakai menjadi perangkat guna

\footnotetext{
7 Abdul Manab, Penelitian PendidikanPendekatan Kualitatif (Yogyakarta: Kalimedia, 2015), 1 .

8 Umar Sidiq, dan Moh. Miftachul Choiri, Metode Penelitian Kualitatif di Bidang Pendidikan (Ponorogo: CV Nata Karya, 2019), 4.
} 
memandu peneliti memahami fenomena, lebih memfokuskan ke dalam daripada luasnya kajian, yang diakhiri dengan teori baru. Memiliki ntujuan untuk mendapat pemahaman yang lebih mendalam mengenai perilaku, proses interaksi, makna suatu tindakan, nilai, pengalaman perseorangan maupun kelompok, yang keseluruhannya berlangsung dalam latar alami. ${ }^{9}$

Penelitian ini berjenis field reasearch, maksudnya adalah penelitian yang dilaksanakan langsung dilapangan guna mendapatkan data yang dibutuhkan. Dalam penelitian ini desain yang digunakan adalah desain penelitian studi kasus, yang mana penelitian mengfokuskan pada fenomena yang kemudian dipahami dan dianalisa secara mendalam. ${ }^{10}$

\section{HASIL DAN PEMBAHASAN}

Sikap tanggung jawab sangat penting pada diri setiap individu, oleh karena itu sifat atau karakter tersebut diharuskan untuk ditanamkan sejak individu masih anak-anak khususnya pada siswa di lingkungan sekolah, Sehingga guru dapat memberi pendidikan karakter terkhusus pada aspek sikap tanggung jawab secara lebih efektif dan efisien kepada siswa didiknya. ${ }^{11}$

Tanggung jawab adalah sikap dan perilaku seseorang untuk melaksanakan tugas dan kewajibannya sebagaimana yang seharusnya dia lakukan, terhadap diri sendiri, masyarakat, lingkungan (alam, sosial, dan budaya), negara, dan tuhan. Apabila dalam penggunaan hak dan kewajiban itu bisa tertib maka akan timbul rasa tanggung jawab. Tanggung jawab yang baik itu apabila antara perolehan hak dan penuaian kewajiban bisa saling seimbang. ${ }^{12}$

Memberikan penanaman sikap tanggug jawab bukanlah hal yang mudah, namun membutuhkan proses yang tidak sebentar. Pentingnya bagi seorang siswa tertanam nilai sikap tanggung jawab, terkhusus sikap tanggung jawab siswa terhadap tugas dalam kegiatan belajarnya. Hal ini akan mengembangkan pribadi siswa menjadi pribadi yang baik bagi dirinya sendiri dan lingkungan sekitarnya. Salah satu cara dalam tertanamnya pencapaian sikap tanggung jawab ini,

\footnotetext{
${ }^{9}$ Abdul Manab, Penelitian PendidikanPendekatan Kualitatif (Yogyakarta: Kalimedia, 2015), 4.

${ }^{10}$ Nana Saodih Sukmadinata, Metode Penelitian Pendidikan. (Bandung: PT Remaja Rosdakarya,2005), 99.

${ }^{11} \mathrm{Ibid}$

${ }^{12}$ Muhammad Mustari, Nilai Karakter Refleksi Untuk Pendidikan (Jakarta: PT Raja Grafindo Persada, 2014), 19.
} 


\section{Penerapan Strategi Joyfull Learning Dalam Penanaman Sikap Tanggung Jawab Siswa (Studi Kasus Pembelajaran IPS Di SMP Negeri 1 Mlarak)}

diperlukan penerapan secara langsung pada pembelajaran di sekolah seperti strategi yang berhasil diterapkan yaitu strategi joyfull learning.

"Joyfull Learning is a learning process that involves student so that they will feel happy, interested, and comfortable in attending the learning process." 13 Pembelajaran yang menyenangkan adalah proses belajar yang melibatkan siswa sehingga akan merasa senang, tertarik, dan nyaman dalam menghadiri proses belajar. Dari beberapa pengertian diatas, dapat ditarik kesimpulan bahwa joyfull Learning adalah strategi pembelajaran yang beratapkan kebahagiaan, kegembiaraan, kenyamanan dalam proses pembelajaran.

Menurut doug lemov dalam buku Teach Like a Champion 2.0 yang dikutip oleh Timothy D. Walker dalam bukunya Teach Like Finland menjelaskan tentang "Faktor Kegembiaraan." Kegembiraan di ruang kelas, saran lemov, merupakan sebuah alat yang dapat digunakan guru untuk meningkatkan pencapaian: tentu saja, momen faktor kegembiaraan tidak selesai disitu. Faktor kegembiraan yang baik di kelas harus menjadi "Pelayan" yang bertujuan untuk mendukung tujuan pembelajaran hari itu. Sebaiknya, ini juga menjadi sesuatu yang dapat anda hidupkan dan matikan dengan cepat. ${ }^{14}$ Tampaknya disini dijelaskan bahwa menjalankan proses pembelajaran harus berprinsip pada sebuah kegembiaraan sebagai strategi yang dipraktikkan. Guru maupun strategi yang diterapkan harus menjadi pelayan sekaligus melayani siswa agar didalam pratik kegiatan belajar mengajar mampu mendorong dan memberikan hasil yang optimal.

Hasil dari penerapan strategi joyfull learning mampu menanamkan sikap tanggung jawab siswa di siswa kelas VII . diketahui bahwa sebelum diterapkannya strategi ini, banyak siswa cenderung mengabaikan tugasnya dan tak acuh pada pembelajaran yang berlangsung. Data yang ada menunjukkan siswa merasakan kebosanan dan kejenuhan terhadap pembelajaran yang berl;angsung, sehingga berakibat pada motivasi siswa untuk semangat dalam belajar.

Strategi joyfull learning yang diterapkan cocok untuk peserta didik dan sederhana untuk dilakukan. Ada beberapa langkah yang biasa diterapkan, yaitu Merayakan Pembelajaran, Bermain dengan murid-murid, kolaborasi lewat kopi,

${ }^{13}$ Vina Anggia Nastitie Ariawan \& Inne Marthyane Pratiwi, Implementing Joyfull Learning Strategy Using Treasure Clue Game Method In Order to Improve Reading Comprehension Skill, Jurnal Prima Edukasia, ISSN: 2460-9927, 5(2), 203-210.

14 Timothy D. Walker, Teach Like Finland Mengajar Seperti Finlandia 33 Strategi Sederhana untuk Kelas yang Menyenangkan. (Jakarta: PT. Gramedia, 2017) cetakan ke 9. 
masuk ke alam, buktikan pembelajaran. Pertama, Merayakan pembelajaran disini adalah cara menghormati jerih payah peserta didik dalam belajar. meluangkan beberapa menit untuk mengapresiasi jerih payah peserta didik. Bentuk merayakannya seperti memberikan ucapan selamat, semangat dsb, karena dengan seperti itu, siswa akan merasa jerih payah siswa dihargai, dan juga tertanam bahwa siswa tersebut dimiliki. Kedua, bermain dengan murid-murid, pada langkah ini perlu mempersiapkan stok permainan. Permainan yang diterapkan diselipkan pada berlangsungnya pembelajaran, bisa diterapkan juga sekedar bermain untuk merefresh kembali semangat belajar peserta didik. Ketiga, kolaborasi lewat kopi. memindahkan tempat belajar siswa ke kantin sekolah. Keempat, masuk kea lam liar. dalam penerapannya sangat sederhana dengan mengajak peserta didik belajar ke luar kelas yang bersentuhan langsung dengan alam, berupa lapangan sekolah, taman sekolah dsb. Kelima, buktikan pembelajaran, praktiknya ini menonjolkan sisi terjadinya interaksi kepada masyarakat dalam bentuk membuktikan pembelajaran, seperti ke pasar.

Dilihat dari hal di atas sudah jelas bahwa penerapan strategi joyfull learning berhasil dalam penanaman sikap tanggung jawab siswa terhadap tugasnya pada pembelajaran IPS. Terbukti dari perubahan karakter yang para siswa alami. Langkah-langkah strategi yang diterapkan yang bertujuan pada penanaman sikap tanggung jawab mampu memberikan perubahan kearah lebih baik, dilihat dari tanggapan guru yang menyatakan bahwa terdapat perubahan pada karakter siswa ke arah yang lebih baik dibuktikan pada tugas siswa yang terselesaikan. Siswa juga menyatakan dengan adanya penerapan strategi ini mendapatkan pengalaman pembelajaran yang menyenangkan.

\section{PENUTUP}

Berdasarkan hasil dari penelitian yang telah peneliti lakukan dan analisis yang telah penulis paparkan, maka dapat diambil kesimpulan sebagai berikut:

1. Penerapan strategi joyfull learning dalam penanaman sikap tanggung jawab siswa dalam pembelajaran di SMP Negeri 1 Mlarak secara konsisten telah menjalankan strategi ini dengan baik. Guru SMP Negeri 1 Mlarak melakukan kegiatan dari awal pembelajaran telah melaksanakan penerapan strategi joyfull learning, dari sejak awal telah menyiapkan landasan data pelaksanaan 
dari langkah merayakan pembelajaran, bermain dengan anak, kolaborasi lewat kopi, masuk ke alam liar, dan buktikan pembelajaran untuk hasil yang lebih baik.

2. Faktor pendukung dan penghambat haruslah sangat diperhatikan. Sebuah perencanaan pastilah harus didukung dengan kesiapan guru maupun sekolah itu sendiri. Salah satunya adalah sarana prasarana yang diharuskan tersedia dan mendukung terlaksananya penerapan strategi joyfull learning. Di SMP Negeri 1 Mlarak dengan adanya penanaman sikap tanggung jawab bisa terlaksana dengan baik jika faktor pendukung maupun penghambat dikelola dengan baik. SMP Negeri 1 Mlarak telah berhasil dalam penerapan strategi joyfull learning karena telah didukung dengan sarana prasarana yang memadai dan pengelolaan guru yang baik, sehingga dampak dalam penanaman sikap tanggung siswa bisa tercapai.

3. Hasil penerapan strategi joyfull learning dalam penaman sikap tanggung tanggung jawab siswa terhadap tugas telah berjalan dengan baik, terbukti dengan langkah-langkah yang telah diterapkan oleh guru di SMP Negeri 1 Mlarak. Terdapatnya langkah-langkah strategi tersebut yang bertujuan pada penanaman sikap tanggung jawab, dan dilihat dari tanggapan guru yang menyatakan bahwa terdapat perubahan pada karakter siswa ke arah yang lebih baik. Siswa juga menyatakan dengan adanya penerapan strategi ini mendapatkan pengalaman pembelajaran yang menyenangkan sekaligus merasakan perubahan sikapnya.

\section{DAFTAR PUSTAKA}

Darmansyah, Strategi Pembelajaran Menyenangkan dengan Humor (Jakarta: PT. Bumi Aksara, 2011).

Kamus Umum Besar Bahasa Indonesia, Departemen Pendidikan dan Kebudayaan, (Jakarta: Balai Pustaka, 1998).

Kurniawan, Syamsul. Pendidikan Karakter: Konsepsi dan Implementasi secara

Terpadu di Lingkungan Keluarga, Sekolah, Perguruan TInggi, dan

Masyarakat, (Yogyakarta: Ar-Ruzz Media, 2013).

Manab, Abdul. Penelitian PendidikanPendekatan Kualitatif (Yogyakarta: Kalimedia, 2015). 
Mustari, Muhammad. Nilai Karakter Refleksi Untuk Pendidikan. (Jakarta: PT Raja Grafindo Persada, 2014).

Rahayu, Ratri. Jurnal konseling gusjigang Vol. 2 No. 1 (Januari-Juni 2016) Print ISSN 2460-1187, Online ISSN 2503-281X. Peningkatan Karakter

Tanggung Jawab Siswa SD Melalui Penilaian Produk Pada Pembelajaran Mind Mapping.

Sukmadinata, Nana Saodih. Metode Penelitian Pendidikan. (Bandung: PT Remaja Rosdakarya,2005).

Sidiq, Umar. dan Choiri, M. Miftachul. Metode Penelitian Kualitatif di Bidang Pendidikan. (Ponorogo: CV Nata Karya, 2019).

Vina \& Inne, Implementing Joyfull Learning Strategy Using Treasure Clue Game Method In Order to Improve Reading Comprehension Skill, Jurnal Prima Edukasia, ISSN: 2460-9927, 5(2), 203-210.

Walker, Timothy D. Teach like Finland Mengajar Seperti Finlandia 33 Strategi Sederhana untuk Kelas yang Menyenangkan. (Jakarta: PT. Gramedia, 2017). 